\title{
SEJARAH TRANSPORMASI SYARIAT ISLAM KEDALAM HUKUM NASIONAL
}

\author{
Oleh \\ Syafri Gunawan \\ Dosen Fakultas Syariah dan Ilmu Hukum IAIN Padangsidimpuan \\ Email: syafrigunawan@iain-padangsidimpuan.ac.id
}

\begin{abstract}
Abstrac
This paper outlines the phases after the Islamic law in Indonesia, so in this paper the focus of the main problem is how to transform Islamic law into positive law in Indonesia. To answer this main issue, it will be divided into sub-headings about the period of acceptance of Islamic law in Indonesia, the bleak period of Islamic law in Indonesia, and the period of enlightenment of Islamic law to make part of the main alternatives in national law. In order to answer this main problem, the author uses the method of literature study by tracing classic books and books as well as other references relating to the history of Islamic law reformation in Indonesia.
\end{abstract}

Kata Kunci; Sejarah, Transpormasi, Syariat, Hukum. dan Nasional

\section{A. Pendahuluan}

Islam merupakan salah satu agama terbesar di dunia, sehingga tidak dapat dibantahkan bahwa hukum Islam turut mempengaruhi perkembangan hukum di jagat raya termasuk di Indonesia sebagai salah satu negara Muslim terbanyak di dunia. Beranjak dari penduduk Muslim terbanyak ini menjadi dasar utama dalam pemberlakuan hukum Islam di bumi pancasila tercinta ini. Sebab Islam dan hukum Islam tidak dapat dipisahkan, sebagaimana digagas oleh H.A.R. Gibb dalam teori otoritasnya yang menyatakan bahwa setiap orang yang sudah menerima Islam sebagai agamanya maka sesungguhnya dia juga harus menerima otoritas hukum Islam sehingga kaum Muslimin mengamalkan hukum Islam dengan penuh kesadaraan sebagai refleksi dari agama Islam yang diyakininya. ${ }^{1}$ Para pemerhati hukum Islam, menamai teori ini dengan teori kredo (syahadat) yang merupakan lanjutan dari prinsip tauhid ke dalam filsafat hukum Islam dengan mengharuskan hukum Islam terhadap orangorang yang telah bersyahadat atau mengucapkan dua kalimat syahadat.

Penerapan hukum Islam di Indonesia, dimulai dari terbitnya Undang-Undang Nomor 7 Tahun 1989 tentang Peradilan Agama sebagai pelindung hak-hak umat Islam dan juga 
berfungsi sebagai payung hukum terhadap produk-produk hukum Islam yang dibutuhkan kaum Muslimin di Indonesia. Namun, meskipun demikian perjalanan hukum Islam di Indonesia melewati perjalanan panjang yang penulis coba uraikan di dalam tulisan ini.

\section{B. Masa Penerimaan Syariat Islam di Indonesia}

Masa penerimaan syariat Islam di bumi nusantara adalah pada masa kerajaan yang ditandai dengan munculnya kerajaan-kerajaan Islam. Pada masa itu hukum Islam sudah diterapkan para sultan (raja) sebagai hukum atau praturan perundang-undangan di masyarakat.

Pada abad 15- 16, Kesultanan Malaka telah menerapkan Peraturan PerundangUndangan yang bersumber dari hukum Islam terutama mengenai permasalahan pernikahan, bahkan tercatat dalam secara bahwa undang-undang ini pernah menjadi salah satu induk peraturan perundangan di nusantara.

Kemudian pada abad ke 16 -17 Kesultanan Samudera Pasai di Nanggrou Aceh Darussalam pun telah menerapkan hukum pidana Islam yaitu peraturan perundang-undangan yang bersumber dari syariat Islam. seperti hukum perzinaan dengan hukuman rajam (dilempar dengan batu) bagi pelaku perzinaan. Selain hukuman rajam di Nanggrou Aceh Daruslam juga kala itu menerapkan hukuman qisas (hukuman yang setimpal atau sama) nyawa dibalas dengan nyawa. Bahkan dalam sejarah Islam tercatat bahwa kerajaan Samudera Pasai adalah merupakan kerajaan Islam pertama di Indonesia.

Kerajaan ini adalah salah satu kerajaan Islam yang menerapkan hukum pidana Islam. Pelaksanaan hukum Islam menyatu dengan pengadilan dan diselenggarakan secara berjenjang. Tingkat pertama dilaksanakan oleh pengadilan tingkat kampung yang dipimpin oleh keuchik. Pengadilan itu hanya menangani perkara-perkara ringan sedangkan pengadilan tingkat pertama dapat mengajukan banding kepada ulee balang (pengadilan tingkat kedua). Selanjutnya dapat di lakukan banding kepada Sultan yang pelaksanaannya dilakukan oleh Mahkamah Agung yang keanggotaannya terdiri atas Malikul Adil, Orang Kaya Sri Paduka Tuan, Orang Kaya Raja Bandhara, dan Faqih (ulama). Pelaksanaan hukum pidana Islam di telah dilaksanakan dikerajaan ini, seperti pelaksanaan hukuman rajam untuk Meurah Pupoek, seorang anak raja yang terbukti zina. Pelaksanaan hukum Islam pada kerajaan ini tidak mengenal jabatan atau golongan, mulai dari keluarga kerajaan sampai rakyat biasa apabila terbukti melanggar hukum Islam pasti akan mendapatkan hukuman yang setimpal dengan perbuatannya. 
Selain kerajaan Samudera Pasai, penerapan hukum Islam juga terdapat di kerajaan Mataram tepatnya pada saat kerajaan Mataram berubah menjadi kerajaan Islam membuat perubahan tata hukum di Mataram, yang mengadili perkara-perkara yang membahayakan keselamatan kerajaan. Istilah pengadilan untuk ini adalah Kisas. Sistem pengadilan di Cirebon dilaksanakan oleh tujuh orang Menteri yang mewakili tiga Sultan, yaitu Sultan Sepuh, Sultan Anom, dan Panembahan Cirebon. Segala acara yang menjadi sidang itu diputuskan menurut Undang-Undang Mataram, Jaya Lengkara, Kontra Menawa dan Adilullah. Namun demikian, satu hal yang tidak dapat dipungkiri, bahwa kedalam Papakem Cirebon itu telah tampak adanya pengaruh hukum Islam. Pengadilan perdata yang ada pada saat itu diubah menjadi Pengadilan Surambi, yang dilaksanakan di serambi-serambi masjid.

Selanjutnya kerajaan Banjar yang tercatat sebagai salah satu kerajaan besar yang memeluk Islam sekalipun konsepsi hukum yang dianut di kerajaan Banjar tidak murni berdasarkan Al-Qur'an dan Sunnah tetapi berpadu dengan adat-istiadat penduduk setempat namun tetap menjadikan hukum Islam bagian dari tata hukum kerajaan Banjar saat itu. Hal ini terlihat dengan adanya mufti-mufti dan qadhi-qadhi, yakni hakim serta penasehat kerajaan dalam bidang agama. Tugas utama mereka adalah menangani masalah-masalah berkenaan dengan hukum keluarga dan hukum perkawinan. Demikian pula Qadhi, di samping menangani masalah-masalah hukum privat, teristimewa juga menyelesaikan perkara-perkara pidana atau dikenal dengan $\mathrm{Had}$. Bahkan dalam tatanan hukum kerajaan Banjar telah dikodifikasikan dalam bentuk sederhana, aturan-aturan hukum yang sepenuhnya berorientasi kepada hukum Islam, kodifikasi itu dikenal dengan Undang-Undang Sultan Adam. Pada akhirnya kedudukan Sultan di Banjar bukan hanya sebagai pemegang kekuasaan dalam kerajaan, tetapi lebih jauh diakui sebagai 'Ulul Amri kaum Muslimin di seluruh kerajaan.

Selanjutnya kerajaan Islam di Sulawesi, yang menurut ahli sejarah sebagai kerajaan yang mula-mula menerima ajaran Islam dengan resmi yang dimulai kerajaan Tallo di Sulawesi Selatan yang kemudian disusul kerajaan Gowa yang merupakan salah satu kerajaan terkuat dan mempunyai pengaruh di kalangan masyarakat.

Dalam tata kerajaan ini ajaran Islam mendapat tempat dalam kekuasaan politik dalam struktur kerajaan yang menduduki jabatan sebagai Parewa Syara' (pejabat syari'at) yang berkedudukan sama dengan Parewa Adek (pejabat adek) yang sebelum datangnya Islam telah ada (pengadilan tingkat II). Parewa syara' dipimpin oleh Kali (Kadli), yaitu pejabat tertinggi dalam syariat Islam yang berkedudukan di pusat kerajaan (pengadilan tingkat III). Di masingmasing Paleli diangkat pejabat bahwan yang disebut imam serta dibantu oleh seorang khatib 
dan seorang Bilal (Pengadilan tingkat I). Para Kadhi dan pejabat jurusan ini diberikan gaji yang diambilkan dari zakat harta, sedekah Idul Fitri dan Idul Adha, kenduri kerajaan, penyelenggaraan mayat dan penyelenggaraan pernikahan. Hal ini terjadi pada saat pemerintahan raja Gowa XV (1637-1653) ketika Malikus Said berkuasa. Sebelumnya raja Gowa sendiri yang menjadi hakim agama Islam.

Begitu juga kerajaan Raja Ali Haji di Riau, dalam catatan sejarah juga telah menerapkan hukum Islam sebab sistem peradilan pada kerajaan Riau pada masa kerajaan Raja Ali haji sistem peradilan kala itu telah tertata dengan rapi. Lembaga peradilan mempunyai kelengkapan layaknya sebuah pengadilan dimasa sekarang. Peradilan terdiri dari, Mahkamah Kerajaan yang bertugas menyelesaikan sengketa dalam kerajaan dan Mahkamah Kecil yang bertugas menangani setiap permasalahan yang timbul dalam masyarakat. Untuk masing-masing mahkamah itu diangkat tiga orang qadhi yang menangani perkara mu'amalah, jinayah dan munakahat.

\section{Masa Suram Syariat Islam di Indonesia}

Sejak kehadiran penjajah Kolonial Belanda ke Indonesia pada abad ke-17 hukum Islam pun menjadi stagnan (tidak berkembang), salah satu penyebabnya adalah munculnya teori reception in complexu. Teori ini, merupakan salah satu politik hukum Kolonial Belanda kala itu untuk menjauhkan hukum Islam. Kolonial Belanda pun terus menyempitkan pergerakan hukum Islam dengan konsep het indiche adatrecht sehingga pada masa itu posisi hukum Islam relatif lemah, menyedihkan, dan tidak mengalami perubahan yang berarti karena dikendalikan hukum adat.

\section{Masa Pencerahan Syariat Islam didalam Hukum Nasional}

Setelah teori reception in complex mulai melemahkan eksistensi hukum Islam di Indonesia dengan memposisikan hukum Islam berada di bawah hukum adat, maka para intelektual Muslim termasuk Hazairin pun tidak mau membiarkan teori ini menggorgroti hukum Islam di bumi pertiwi tercinta ini maka ia membuat sebuah teori reception a contrario yang menyatakan bahwa hukum adat dapat berlaku apabila tidak bertentangan dengan hukum Islam. ${ }^{2}$ Tidak hanya teori itu, tetapi masih banyak teori lain seperti teori receptive exit, teori reception a contrario, teori eksistensi, dan sebagainya.

Khususnya pada masa pasca kemerdekaan para intelektual Muslim terus memperjuangkan mencerahkan kembali hukum Islam agar diakui sebagai subsistem hukum yang hidup di masyarakat, bahkan mereka terus memperjuangkan hukum Islam ketingkat 


\section{-Jurnal El-Qanuniy}

Volume 6 Nomor 1 Edisi Januari-Juni 2020

legalisasi dan legislasi. Legislasi hukum Islam kedalam hukum nasional ini dapat dilihat pada beberapa undang-undang sebagai berikut :

\begin{tabular}{|c|c|c|}
\hline \multirow[t]{2}{*}{ No } & \multicolumn{2}{|c|}{ Transpormasi Hukum Islam Kedalam Hukum Nasional } \\
\hline & Secara Konteks dan Subtansi & Secara Substansional \\
\hline 1 & & $\begin{array}{l}\text { Undang-Undang Nomor } 1 \text { Tahun } 1974 \\
\text { tentang Perkawinan }\end{array}$ \\
\hline 2 & $\begin{array}{l}\text { Undang-Undang Nomor } 7 \text { Tahun } 1989 \\
\text { tentang Peradilan Agama }\end{array}$ & \\
\hline 3 & & $\begin{array}{l}\text { Undang-Undang Nomor } 2 \text { Tahun } \\
\text { tentang Sistem Pendidikan Nasional }\end{array}$ \\
\hline 4 & $\begin{array}{l}\text { Undang-Undang Nomor } 17 \text { Tahun } \\
1999 \text { tentang Penyelenggaraan Ibadah } \\
\text { Haji }\end{array}$ & \\
\hline 5 & $\begin{array}{l}\text { Undang-Undang Nomor } 38 \text { Tahun } \\
1999 \text { tentang Pengelolaan Zakat }\end{array}$ & \\
\hline 6 & & $\begin{array}{l}\text { Undang-Undang Nomor } 44 \text { Tahun } 1999 \\
\text { tentang Penyelenggaraan Otonomi Khusus } \\
\text { Nanggroe Aceh Darussalam }\end{array}$ \\
\hline 7 & Kompilasi Hukum Islam (KHI) & \\
\hline 8 & $\begin{array}{l}\text { Qanun Provinsi Nanggroe Aceh } \\
\text { Darussalam Nomor 5 Tahun } 2000 \\
\text { tentang Pelaksanaan Syari'at Islam }\end{array}$ & \\
\hline 9 & $\begin{array}{l}\text { Undang-Undang Nomor } 41 \text { Tahun } \\
2004 \text { tentang Wakaf. }\end{array}$ & \\
\hline 10 & $\begin{array}{l}\text { Undang-Undang Nomor } 3 \text { Tahun } 2006 \\
\text { tetang Perubahan Undang-Undang } \\
\text { Nomor } 7 \text { Tahun } 1989 \text { tentang } \\
\text { Peradilan Agama berkaitan dengan } \\
\text { perluasan kewenangan Peradilan } \\
\text { Agama dibidang ekonomi syari'ah. }\end{array}$ & \\
\hline 11 & $\begin{array}{l}\text { Undang-Undang } 21 \text { Tahun } 2008 \\
\text { tentang Perbankan Syariah. }\end{array}$ & \\
\hline 12 & $\begin{array}{l}\text { Perma Nomor } 2 \text { Tahun } 2008 \text { tentang } \\
\text { Kompilasi Hukum Ekonomi Syariah } \\
\text { (KHES). }\end{array}$ & \\
\hline 13 & $\begin{array}{l}\text { Undang-Undang Nomor } 19 \text { Tahun } \\
2008 \text { tentang Surat Berharga Syariah } \\
\text { Negara, dan Undang-Undang Nomor } \\
23 \text { Tahun } 2011 \text { tentang Pengelolaan } \\
\text { Zakat. }\end{array}$ & \\
\hline
\end{tabular}

Terutama di era reformasi, pemerintah lebih akomodatif terhadap tatanan dan kebudayaan yang hidup dan berkembang di masyarakat terutama kegiatan-kegiatan keagamaan, sehingga kegiatan sosial keagamaan di masyarakat Indonesia semakin hari 
semakin maju dan berkembang, hal tersebut tercermin dengan ditetapkannya Undang-Undang Nomor 17 Tahun 1999 tentang Penyelenggaraan Ibadah Haji, Undang-Undang Nomor 38 Tahun 1999 tentang Pengelolaan Zakat.

Lalu pada masa pemerintahan B. J. Habibie yang memimpin Indonesia pada 21 Mei 1998 sampai 20 Oktober 1999, beliau mengesahkan undang-undang tentang otonomi daerah yaitu Undang-Undang Nomor 22 Tahun 1999 tentang Pemerintahan Daerah (Pemda) yang kemudian menjadi landasan kokoh bagi intelektual Muslim membuat Peraturan Daerah (Perda) yang bernuansa islami atau memberlakukan hukum Islam. ${ }^{3}$ Terutama provinsi Nanggroe Aceh Daeussalam (NAD) yang mendapatkan Undang-Undang Nomor 44 Tahun 1999 tentang Penyelenggaraan Otonomi Khusus Nanggroe Aceh Darussalam membuat provinsi NAD banyak menerbitkan Qanun atau Perda Syariat Islam.

Maka pada masa pemerintahan K.H. Abdurrahman Wahid yang dikenal dengan sebutan Gus Dur pemimpin Indonesia sejak 20 Oktober 1999 hingga 23 Juli 2001, sekalipun beliau sangat menentang kaum Muslimin yang mengutamakan formalisasi ajaran agama Islam ke dalam hukum nasional namun kegiatan sosial keagamaan termasuk hukum Islam berjalan sebagaimana pada pemerintahan sebelumnya. ${ }^{4}$ Sekalipun hukum Islam secara formal di tingkat nasional relatif tidak ada namun di daerah tetap muncul peraturan yang bernuansa hukum Islam tepatnya pada tahun 2000 yaitu Qanun Provinsi NAD Nomor 5 Tahun 2000 tentang Pelaksanaan Syari'at Islam. Berdasarkan Qanun ini, agama selain Islam diakui keberadaannya di NAD yangmana semuua non Muslim harus dihormati dan dilindungi keberadaan mereka serta diberikan kebebasan untuk beribadat melaksanakan ajaran dan kewajiban sesuai dengan agama mereka masing-masing sehingga non Muslim tidak perlu merasa resah terhadap perlindungan beragama di NAD. ${ }^{5}$

Lalu pada masa pemerintahan Megawati Soekarno Putri, yang menjadi pemimpin Indonesia pada 23 Juli 2001 hingga 20 Oktober 2004 eksistensi hukum Islam masih tetap sama dengan pemimpin sebelumnya. Bahkan pada pemerintahannya disahkan UndangUndang Nomor 18 Tahun 2001 tentang Otonomi Khusus bagi Provinsi Daerah Istimewa Aceh sebagai Provinsi Nangroe Aceh Darussalam. ${ }^{6}$

Kemudian berlanjut ke masa pemerintahan Susilo Bambang Yodhoyono yang akrab disapa SBY yang memimpin Indonesia dua priode yaitu priode 2004- 2009 dan priode 20092014. Pada masa pemerintahannya, perkembangan kehidupan dan kegiatan sosial keagamaan berjalan sebagaimana sebelumnya, serta mengalami kemajuan dengan lahirnya berbagai peraturan perundang-undangan mengenai legalisasi hukum nasional dalam konteks penerapan 
hukum Islam ${ }^{7}$ diantaranya: Undang-Undang Nomor 41 Tahun 2004 tentang Wakaf yang disahkan pada tanggal 27 Oktober 2004, Undang-Undang Nomor 3 Tahun 2006 tetang Perubahan Undang-Undang Nomor 7 Tahun 1989 tentang Peradilan Agama berkaitan dengan perluasan kewenangan Peradilan Agama dibidang ekonomi syari'ah, Undang-Undang 21 Tahun 2008 tentang Perbankan Syariah, Perma Nomor 2 Tahun 2008 tentang Kompilasi Hukum Ekonomi Syariah (KHES), Undang-Undang Nomor 19 Tahun 2008 tentang Surat Berharga Syariah Negara, dan Undang-Undang Nomor 23 Tahun 2011 tentang Pengelolaan Zakat.

Selanjutnya pada pemerintahan Jokowidodo dan Jusuf Kalla sempat dipernah melarang munculnya peraturan daerah baru yang berlandaskan syariat Islam. Namun, khusus daerah Aceh, akan memberikan keistimewaan. Perda syariat Islam dinilai akan menciptakan dikotomi tatanan sosial di masyarakat dan menganggu kemajemukan NKRI yang berlandaskan Bhineka Tunggal Ika. $^{8}$ Beberapa peraturan daerah yang telah diterbitkan disinyalir bertolak belakang dengan prinsip Negara Kesatuan Republik Indonesia dan Pancasila. Hal tersebut dikuatkan dengan beredarnya Perda-Perda yang bernuansa agama.

Meski demikian, Aceh dengan pengkhususan tersebut mengeluarkan Qanun Aceh Nomor 8 Tahun Tentang Pokok-Pokok Syariat Islam. Hal tersebut dilaksanakan dalam rangka rangka pelaksanaan Nota kesepahaman antara Pemerintah Republik Indonesia dan Gerakan Aceh Merdeka (Memorandum of Understanding between the Goverment of Republic of Indonesia and the Free Aceh Movement, Helsinki 15 Agustus 2005), Pemerintah Republik Indonesia dan Gerakan Aceh Merdeka menegaskan komitmen mereka untuk menyelesaikan konflik Aceh secara damai, menyeluruh, berkelanjutan dan bermartabat bagi semua, dan para pihak bertekad untuk menciptakan kondisi sehingga Pemerintahan Rakyat Aceh dapat diwujudkan melalui suatu proses yang demokratis dan adil dalam Negara Kesatuan Republik Indonesia. $^{9}$

Adanya penjelasan di atas, maka dapat dibagi beberapa priode dalam eksisteni hukum Islam di Indonesia, sebagai berikut:

\begin{tabular}{|c|c|c|c|c|}
\hline Masa & Abad/Tahun & Pemerintahan & Pemimpin & Hukum Islam \\
\hline $\begin{array}{l}\text { Masa } \\
\text { kejayaan }\end{array}$ & $\begin{array}{l}\text { Abad ke } 7 \\
(1267 \mathrm{M}) \mathrm{M}- \\
16 \mathrm{M}\end{array}$ & $\begin{array}{l}\text { Kerajaan } \\
\text { Samudra } \\
\text { Pasai- } \\
\text { Kerajaan }\end{array}$ & $\begin{array}{l}\text { Sultan Malik } \\
\text { as-Saleh- }\end{array}$ & $\begin{array}{l}\text { Hukum Islam sebagai } \\
\text { rujukan }\end{array}$ \\
\hline
\end{tabular}




\begin{tabular}{|c|c|c|c|c|}
\hline $\begin{array}{l}\text { Masa } \\
\text { Kemundura } \\
\mathrm{n}\end{array}$ & $\begin{array}{l}\text { Abad ke 16- } \\
19 \mathrm{M}\end{array}$ & & & Hukum Islam diminimalisir \\
\hline \multirow{2}{*}{$\begin{array}{l}\text { Masa } \\
\text { Kebangkita } \\
\text { n }\end{array}$} & 1945- & Orde Lama & Soekarno & $\begin{array}{l}\text { Pengumpulan dana zakat } \\
\text { ditangani oleh presiden }\end{array}$ \\
\hline & & Orde Baru & Soeharto & KHI \\
\hline \multirow{5}{*}{$\begin{array}{l}\text { Masa } \\
\text { Keterbukaa } \\
\text { n }\end{array}$} & 1998-1999 & Reformasi & B.J. Habibie & $\begin{array}{l}\text { UU Peradilan Agma, UU } \\
\text { Zakat, UU Ibadah Haji, dsb. }\end{array}$ \\
\hline & $1999-2001$ & & $\begin{array}{l}\text { Abdurrahman } \\
\text { Wahid }\end{array}$ & $\begin{array}{l}\text { Tidak banyak perundang- } \\
\text { undnagan yang disahkan }\end{array}$ \\
\hline & $2001-2004$ & & $\begin{array}{l}\text { Megawati } \\
\text { Soekarnoputri }\end{array}$ & $\begin{array}{l}\text { UU No } 1 \text { Tahun } 2004 \\
\text { tentang DI. NAD }\end{array}$ \\
\hline & $2004-2014$ & & $\begin{array}{l}\text { Susilo } \\
\text { Bambang } \\
\text { Yudhoyono }\end{array}$ & $\begin{array}{l}\text { UU No. } 41 \text { Tahun } 2004 \\
\text { tentang Wakaf, Dll }\end{array}$ \\
\hline & $\begin{array}{l}\text { 2014- } \\
\text { sekarang }\end{array}$ & & Jokowi Dodo & $\begin{array}{l}\text { melarang munculnya Perda } \\
\text { baru yang berlandaskan } \\
\text { syariat Islam }\end{array}$ \\
\hline
\end{tabular}

\section{E. Transformasi Hukum Islam menjadi Hukum Nasional}

Transformasi merupakan suatu usaha untuk mengadakan perubahan terhadap sesuatu yang telah ada menjadi sesuatu yang baru, antara lain dengan penyesuaian dan perubahan. Pada bidang hukum, transformasi sering dipakai dalam arti penyesuaian hukum dengan kebutuhan masyarakat. Proses atau upaya transformasi hukum Islam ke dalam tata hukum nasional dimaksudkan sebagai usaha menerapkan hukum Islam yang normatif menjadi hukum Islam yang positif atau yang sering disebut usaha positifisme hukum Islam ke dalam tata hukum Indonesia. ${ }^{10}$

Legislasi hukum Islam di Indonesia dapat dibaca melalui masuknya Islam di Indonesia. Secara sosiologis dan kultural, hukum Islam telah menyatu dan menjadi hukum yang hidup. Posisi setiap golongan atau kelompok adalah sama terhadap kekosongan hukum nasional. Semua pihak mempunyai dan kesempatan yang sama untuk memasukkan konsepkonsep tentang sistem dan materi hukum nasional yang akan diperjuangkan. ${ }^{11}$ Untuk 
mewujudkan hukum nasional bagi bangsa yang terdiri dari berbagai suku bangsa dengan agama dan kebudayaan yang berbeda merupakan hal yang tidak mudah. Political will juga merupakan hal yang mempengaruhi terbentuknya suatu hukum nasional.

Pembentukan hukum Islam ke dalam hukum nasional sesungguhnya menimbulkan masalah baru. Hal tersebut berarti harus ada unifikasi hukum meskipun memiliki sisi positif dalam hal memenuhi kebutuhan umat Islam. Oleh karena itu, dibutuhkan unifikasi yang mana tidak dapat terjadi dengan sendirinya, melainkan membutuhkan kekuatan politik. ${ }^{12}$ Terdapat tiga alasan yang memberi posisi yuridis terhadap hukum Islam di Indonesia yaitu :

1. Dasar filosofis, yang memberi injeksi luar biasa terhadap kelahiran sikap epistimologi Islam yang mempunyai sumbangan besar bagi tumbuhnya pandangan hidup, cita moral, dan hukum dalam kehidupan sosio kultural masyarakat;

2. Dasar sosiologis, yang menyiratkan bahwa tingkat religiusitas yang telah menyebar ke berbagai tempat dan wilayah sehingga hal tersebut terpatri secara kuat dan berlangsung terus-menerus;

3. Dasar yuridis, dapat dilihat dari akar sejarah bangsa Indonesia di setiap masanya. Hukum Islam sejak pra kemerdekaan hingga reformasi senantiasa memiliki tempat, meskipun presentasi setiap masanya berbeda-beda. ${ }^{13}$

Upaya transformasi hukum Islam ke dalam hukum nasional dilakukan dengan penelaahan/pengkajian kitab-kitab, wawancara dengan para ulama, lokakarya terhadap hasil penelaahan kitab dan hasil wawancara serta terakhir dengan studi perbandingan ke negaranegara Islam atau negara-negara yang menggunakan hukum Islam sebagai hukum nasionalnya. Transformasi hukum Islam sebagai salah satu tatanan hukum ke dalam hukum nasional, secara umum terakomodasi dalam sasaran pembangunan nasional di bidang hukum khususnya tentang materi hukum nasional. Namun penerapan dan penegakan hukum dalam masyarakat tergantung kepada 4 unsur yaitu :

1. Perangkat hukum yang menjamin kepastian, perlindungan, dan ketertiban hukum yang intinya keadilan dan kebenaran;

2. Aparatur penegak hukum yang mampu atau mempunyai kesanggupan menerapkan hukum dan menyelami rasa keadilan;

3. Kesadaran hukum masyarakat yang intinya menghargai dan mematuhi hukum yang berlaku;

4. Sarana dan prasarana yang dibutuhkan baik berupa kelembagaan maupun fisik. ${ }^{14}$ 
Tujuan pembentukan hukum Islam menjadi hukum nasional adalah salah satu langkah untuk menemukan kesesuaian antara hukum Islam dengan hukum nasional. Daniel S. Lev mengemukakan bahwa hukum dalam Islam dipisahkan dari kepentingan segenap umat dan hukum Islam ialah hukum ketuhanan yang berlaku bagi setiap Muslim dimanapun berada. Sedangkan hukum nasional merupakan hukum produk lembaga kenegaraan yang berlaku dalam batas-batas negara yang bersangkutan. ${ }^{15}$

Gagasan tentang pemberlakuan syariat Islam telah ada di Indonesia. Syariat Islam sebagai bagian dari tuntutan masyarakat Islam secara resmi dibicarakan dan diputuskan melalui piagam Jakarta (Jakarta Charter). Hal tersebut merupakan fakta sejarah tentang kesepakatan para founding father untuk mencantumkan kalimat "dengan kewajiban untuk menjalankan syariat Islam bagi pemeluk-pemeluknya" setelah sila Ketuhanan dalam pembukaan UUD 1945 demi memelihara persatuan bangsa dan kerukunan hidup beragama. ${ }^{16}$ Pengakuan adanya Piagam Jakarta berarti pengakuan pula akan pengaruhnya terhadap UUD 1945. Jiwa dari Piagam Jakarta tersebut yang melahirkan berbagai produk perundangundangan yang bersumber dari hukum Islam. ${ }^{17}$

Melihat keterangan tersebut, maka hukum Islam tidak diragukan lagi telah memiliki peluang besar dan menjadi bagian hukum nasional. Pada hal tersebut, hukum Islam dalam setiap pengambilan kebijakan pemerintah, baik dalam bentuk legalisasi hukum nasional atau peraturan daerah maupun dalam bentuk kebijakan-kebijakan lain sangat diperlukan. Maka, diperlukan sumber daya manusia yang handal dan mampu berijtihad dalam mengakomodasi substnsi-substansi hukum Islam dalam setiap legalisasi hukum yang akan dibuat. Ijtihad yang dewasa ini dibutuhkan oleh kepentingan Indonesia ialah ijtihad terhadap lembaga-lembaga yang memiliki kewenangan dan otoritas di bidang hukum. Adapun contoh dalam produk legalisasi nasional dalam Intruksi Presiden Nomor 1 Tahun 1991 tentang Kompilasi Hukum Islam.

Setelah lahirnya Undang-Undang Nomor 7 Tahun 1989 tentang Peradilan Agama, sebagai sebuah lembaga peradilan yang diperluntukkan khusus bagi umat Islam, maka hal tersebut mempunyai nilai strategis untuk memicu lahirnya suatu peraturan-peraturan baru berikutnya sebagai pelengkap dalam konteks Peradilan Agama kedepan. Satu tahun lima bulan setelah disahkannya Undang-Undang Peradilan Agama, nilai strategis tersebut menjadi kenyataan, yakni dengan lahirnya KHI berdasarkan Instruksi Presiden RI Nomor 1 Tahun 1991. KHI disusun dengan tujuan untuk memberikan pedoman bagi para hakim agama dalam memutus perkara-perkara dalam lingkup Peradilan Agama. ${ }^{18}$ 
Rancangan Undang-Undang tersebut telah selesai dirumuskan setelah lebih dahulu dilakukan studi banding ke beberapa negara, seperti Malaysia, Singapura, Pakistan, Saudi Arabia, dan Mesir. Kenyataan dalam masyarakat bahwa KHI tidak luput dari kritik yang mengandung kontroversi. Pembentukan KHI berkaitan erat dengan kondisi hukum Islam di Indonesia. Para tokoh yang banyak terlibat dalam penyusunan KHI diantaranya Hasan Basri, Bustanul Arifin, Masrani Basran, dan M. Yahya Harahap. Menurut Hasan Basri, KHI sebagai keberhasilan besar umat Islam Indonesia pada pemerintahan orde baru. Sebab, umat Islam nantinya akan mempunyai pedoman fikih yang seragam dan hukum positif yang yang wajib dipatuhi oleh seluruh umat Islam Indonesia. ${ }^{19}$

Sebelum adanya KHI, untuk mendapatkan kesatuan hukum yang memeriksa dan memutus perkara, maka para hakim Pengadilan Agama dianjurkan menggunakan kitab-kitab sebagaimana diatur dalam Peraturan Pemerintah Nomor 45 Tahun 1957 tentang Pembentukan Pengadilan Agama/Mahkamah Syar'iyah di luar Jawa dan Madura. Namun, hal tersebut membuka peluang bagi terjadinya pembangkangan dan setidaknya keluhan ketika pihak yang kalah mempertanyakan kitab yang tidak menguntungkan baginya. Bahkan, sering terjadi pula para hakim berselisih tentang pemilihan kitab rujukan. ${ }^{20}$

Ide untuk mengadakan Kompilasi Hukum Islam baru muncul sekitar tahun 1985. Kemunculannya merupakan hasil kompromi antara pihak Mahkamah Agung dengan Departemen Agama. Langkah tersebut mendapat dukungan banyak pihak. Pada bulan Maret 1985, Presiden Soeharto mengambil prakarsa sehingga terbitlah SKB Ketua Mahkamah Aging dan Menteri Agama yang membentuk proyek KHI. Tugas pokok proyek tersebut ialah untuk melaksanakan usaha pembangunan hukum Islam melalui yurisprudensi dengan jalan kompilasi hukum. Sasarannya dengan mengkaji kitab-kitab yang dipergunakan sebagai landasan putusan-putusan hakim agar sesuai dengan perkembangan masyarakat Indonesia untuk menuju hukum nasional. ${ }^{21}$

Dorongan pemerintah untuk segera mengesahkan Kompilasi Hukum Islam muncul dari berbagai pihak. Hanya saja, masih terdapat perbedaan pandangan tentang produk hukum yang akan mewadahi kompilasi tersebut. Akan tetapi, dikhawatirkan akan berlarut-larut jika harus dirancang kembali menjadi satu undang-undang. Pada tanggal 10 Juni 1991, presiden menandatangani Instruksi Presiden RI Nomor 1 Tahun 1990. Sejak saat itu, secara formal berlakulah Kompilasi Hukum Islam di seluruh Indonesia sebagai hukum materil yang dipergunakan di lingkungan Peradilan Agama. ${ }^{22}$ Maka, dapat dikatakan bahwa sejak dini kegiatan tersebut lancar dengan mendapat dukungan oleh kepala negara. 


\section{F. Penutup}

Konvigurasi persoalan-persoalan di masyarakat yang semakin hari kian kompleks, sehingga menuntut pemerintah untuk mencari solusi yang akurat dari ragam macaman hukum yang ada dalam menciptakan produk-produk hukum yang mampu mengkaver persoalanpersoalan yang hadir di tengah-tengah masyarakat. Hal ini merupakan salah satu faktor yang menglegislasikan hukum Islam di dalam hukum nasional, maka tidak mengherankan apabila saat ini sudah banyak hukum Islam yang diangkat dan dikuatkan menjadi hukum negara mulai Undang-Undang Nomor 7 Tahun 1989 tentang Peradilan Agama, Kompilasi Hukum Islam (KHI) sampai kepada Undang-Undang Perbankan Syariah.

Term hukum Islam, sering disebut as-syari'ah al-Islamiyah (Islamic law) atau al-figh al-Islamy (Islamic jurispundence) memiliki lika-liku sejarah di Indonesia yang mana disetiap masa memiliki nuansa tersendiri mulai masa kerajaan, masa Kolonial Belanda, sampai kepada masa kemerdekaan saat ini membuat hukum Islam berkembang sesuai dengan konteks budaya masyarakat Indonesia.

\section{End Note :}

${ }^{1}$ Mahsun Fuad, Hukum Islam Indonesia, (Yogyakarta: LKis Yogyakarta, 2005), hlm. 49-50.

2 Ahmad Syafii Maarif, Islam dan Pancasila Sebagai Dasar Negara, (Jakarta: Pustaka LP3IS Indonesia, 2006), hlm. 9.

${ }^{3}$ Juanda, Hukum Pemerintah Daerah, (Bandung: PT Alumni, 2002), h. 192.

${ }^{4}$ Ibid., hlm. 124.

5 Marzuki Abubakar, Syari'at Islam di Aceh: Sebuah Model Kerukunan dan Kebebasan Beragama, (IAIN Ar-Raniry, Jurnal Hukum Islam dan Pranata Sosial, 2001), hlm. 7-8.

${ }^{6}$ Ibid., hlm. 126.

${ }^{7}$ Ibid, hlm. 127.

8 Republika, Kecuali di Aceh, Jokowi-JK Bakal Larang Perda Syariat Islam, 2014 http://www.republika.co.id.

9 Jaringan Dokumentasi dan Inforrmasi Hukum Aceh, Qanun Aceh Nomor 8 Tahun Tentang PokokPokok Syariat Islam , 2014, h1. http://jdih.acehprov.go.id, diunduh tanggal 5 Januari 2016.

${ }^{10}$ Rahmawati Pardjaman, Transformasi Nilai-Nilai Syariah ke dalam Sistem Hukum Nasional; Sebuah Pendekatan Hermeneutika, (Al-Adalah Vol XI, 2013), hlm. 250.

${ }^{11}$ Ibid, hlm. xviii.

${ }^{12}$ Ibid., h. 140.

${ }^{13}$ Sirajuddin, Legalisasi Hukum Islam di Indonesia, (Yogyakarta: Pustaka Pelajar Offset dan IAIN Bengkulu, 2008), hlm. 143-144. $255-256$.

${ }^{14}$ Rahmawati Pardjaman, Transformasi Nilai-Nilai Syariah ke dalam Sistem Hukum Nasional, hlm.

${ }^{15}$ Sirajuddin, Loc.Cit., h. 140.

${ }^{16}$ Sri Soemarti, Hukum Tata Negara Indonesia, (Bandung: PT Remaja Rosdakarya, 2014), h. 107.

${ }^{17}$ Hendra Gunawan, "Sistem Peradilan Islam” Pada Jurnal el-Qanuniy: Jurnal Ilmu-Ilmu Kesyariahan dan Pranata Sosial Fakultas Syariah dan Ilmu Hukum IAIN Padangsidimpuan, Volume 5 Nomor 1 Edisi Januari-Juni 2019, hlm. 90-103

${ }^{18}$ Salman Maggalatung, Op.Cit., h. 190-191

19 Abdurrahman, Kompilasi Hukum Islam di Indonesia, (Jakarta: Akademika Pressindo, 2007), h. 20. 


\footnotetext{
${ }^{20}$ Ibid., h. 22-23.

${ }^{21}$ Ibid., h. 33.

${ }^{22}$ Ibid., h. 50.
}

\section{DAFTAR PUSTAKA}

Fuad, Mahsun,. Hukum Islam Indonesia, Yogyakarta: LKis Yogyakarta, 2005.

Maarif, Ahmad Syafii,. Islam dan Pancasila Sebagai Dasar Negara, Jakarta: Pustaka LP3IS Indonesia, 2006.

Juanda, Hukum Pemerintah Daerah, Bandung: PT Alumni, 2002.

Abubakar, Marzuki,. Syari'at Islam di Aceh: Sebuah Model Kerukunan dan Kebebasan Beragama, Jurnal Hukum Islam dan Pranata Sosial, IAIN Ar-Raniry, 2001.

Pardjaman, Rahmawati,. Transformasi Nilai-Nilai Syariah ke dalam Sistem Hukum Nasional; Sebuah Pendekatan Hermeneutika, Jurnal Al-Adalah Volume XI, 2013.

Sirajuddin, Legalisasi Hukum Islam di Indonesia, Yogyakarta: Pustaka Pelajar Offset dan IAIN Bengkulu, 2008.

Soemarti, Sri,. Hukum Tata Negara Indonesia, Bandung: PT Remaja Rosdakarya, 2014.

Abdurrahman, Kompilasi Hukum Islam di Indonesia, Jakarta: Akademika Pressindo, 2007.

Gunawan, Hendra, "Sistem Peradilan Islam” Pada Jurnal el-Qanuniy: Jurnal Ilmu-Ilmu

Kesyariahan dan Pranata Sosial Fakultas Syariah dan Ilmu Hukum IAIN Padangsidimpuan,

Volume 5 Nomor 1 Edisi Januari-Juni 2019. 